\title{
Age-Related Histological Changes in Vena Caval System of Human Foetus and Adult: A Comparative Study
}

\author{
Robert Kevin Fernandez ${ }^{1}$, Chandni Gupta ${ }^{2}$, Sneha Guruprasad Kalthur ${ }^{3 *}$
}

\footnotetext{
OPEN ACCESS

Citation: Robert Kevin Fernandez, Chandni Gupta, Sneha Guruprasad Kalthur. Age-Related Histological Changes in Vena Caval System of Human Foetus and Adult: A Comparative Study. Ethiop J Health Sci. 2020;30(3):387.doi:http://dx.doi.org/10.4 314/ejhs.v30 i 3.10

Received: October 4, 2019

Accepted: November 28, 2019

Published: May 1, 2020

Copyright: (C2020 Robert K., et al. This is an open access article distributed under the terms of the Creative Commons Attribution License, which permits unrestricted use, distribution, and reproduction in any medium, provided the original author and source are credited. Funding: Nill

Competing Interests: The authors declare that this manuscript was approved by all authors in its form and that no competing interest exists.

Affiliation and Correspondence:

${ }^{1}$ Department of Anatomy and Medical Illustration, Amrita School of Medicine, Amrita Institute of Medical Sciences, Kochi

${ }^{2}$ Department of Anatomy, Kasturba Medical College, Manipal, Manipal Academy of Higher Education, Manipal

${ }^{3}$ Department of Anatomy, Kasturba Medical College, Manipal, Manipal Academy of Higher Education, Manipal

*Email: guruprasad@manipal.edu
}

\begin{abstract}
BACKGROUND: It has been documented that cardiac musculature is present in both venae cavae, and they contract together with the atrium, contributing to the pumping mechanism of the heart. So, in the present study, we measured the relative thicknesses of the three histological layers at formation, termination and intermediate levels of the venae cavae along with their histological characteristics.
\end{abstract}

MATERIALS AND METHODS: Ten foetal and 10 adult cadavers were used. The Superior and Inferior Venae Cavae from all three regions were excised and processed for histology. The qualitative and quantitative features of the vessels were observed and recorded. The data thus obtained was then assessed statistically.

RESULTS: In superior vena cava, the tunica intima grows actively especially during late gestation. The tunica media shows active growth. The tunica adventitia growth is significant at the middle and termination levels. In inferior vena cava, the tunica intima grows actively at the level of formation. The tunica media shows the active overall growth during early gestation. The tunica adventitia shows active growth during late gestation. In qualitative analysis the plump, spindle-shaped primitive mesenchymal cells were observed. Muscle and collagen fibers show reciprocal abundance with increasing age, with the former being lesser in amount than the latter in earlier stages. Appearance of vasa vasorum was notable from 2nd trimester. The cardiac myocytes were located in the middle and outer tunics of the superior vena cava.

CONCLUSION: Cardiac musculature was absent in the inferior vena; however, the vessel shows advanced rate of overall development.

KEYWORDS: Venae Cavae, Cardiac musculature, Histological, Quantitative

\section{INTRODUCTION}

The venae cavae form the major conduits for flow of deoxygenated blood from systemic circulation into the heart. The blood enters into the right atrium and from there into the right ventricle through the tricuspid valve, and finally to the lungs via the pulmonary arteries for oxygenation. 
The superior vena cava measures $7 \mathrm{~cm}$ in length and $2 \mathrm{~cm}$ in width. It lies in superior (extrapericardial part) and middle mediastinum (intrapericardial part). It drains blood from the upper part of the body into the right atrium (1).

The inferior vena cava measure $20-23 \mathrm{~cm}$ in length and $2.5 \mathrm{~cm}$ in width and extends along the greater part of the posterior abdominal wall following an upward course and drains the part of the body inferior to the diaphragm. In foetal life, it conveys mixed blood, the oxygenated blood being derived from the left umbilical vein via the ductus venosus. Except for a semilunar valve at its atrial opening which regulates blood flow into the left atrium via the foramen ovale is rudimentary in adult life; the inferior vena cava is devoid of valves. (1)

The venae cavae are classic examples of large veins but lack valves. The gross thickness of the vessel wall is much thicker and the caliber of the lumen is much larger, as compared to those of an artery of comparable proportions. Like all veins, their walls consist of three basic layers, namely, the tunica intima, the tunica media and the tunica adventitia from within outwards. The tunica intima consists of endothelium made up of a single layer of flattened endothelial cells resting on a basal lamina constituted mainly by glycoprotein. The tunica media consists of smooth muscle and elastic fibres in amounts much lesser than those found in arteries, while the amount of connective tissue comprising of collagen fibres, and exceeds that in arteries. The tunica adventitia is the thickest layer which contrasts with the media being the thickest in arteries and consists of connective tissue comprised mainly of collagen fibres that forms a meshwork which spirals around the vessel. The adventitia also contains a remarkable amount of smooth muscle and elastic fibres that run predominantly in the longitudinal direction. The fibres of the intima and adventitia run longitudinally, whereas those of the media run circularly. The vessels are supplied by vasa vasorum that may penetrate up to the intima due to low venous pressure and oxygen tension. Nervi vascularis are also noted, but their number is lesser than that in arteries (2).

Previous studies have documented the presence of cardiac musculature in both venae cavae, the implications of which are noteworthy. Immunohistochemical analysis has detected an atrial natriuretic polypeptide-like substance in the cranial vena cava, which is a peptide hormone known to be synthesized by cardiac muscle cells in walls of atria. Thus, cardiac musculature in the vena cava may be playing a part in the endocrine function of atrial musculature (3). The venae cavae are, therefore, histologically regarded as extensions of the atrium and contract together with the atrium, working as a functional valve contributing to the pumping mechanism of the heart (4). The muscular component of the intrapericardial segment of the superior venae cavae may be regarded as a functional sphincter controlling blood flow to the atrium as well as stopping blood flow during the arterial systole (5). Cardiac musculature of the superior vena cava in the common tree shrew (Tupaia glis) consists of well-developed cardiac muscle layers in the tunica media extending from the atrium to the root of subclavian vein.

The common tree shrew is one of the most primitive mammals, so cardiac musculature in its vessels may be postulated to be a common characteristic in lower mammals. Typical myocyte structure associated with nerve endings indicate that this musculature may serve as a regulatory pump for venous return and as a reservoir of blood under rapid heart rate conditions (6). Examination of venae cavae in fowl revealed cardiac musculature extending from atrium to the root of subclavian vein in the superior vena cava and from atrium to the superior margin of liver in the inferior vena cava. The morphology and pattern of distribution of such musculature in the vessel wall suggests that it shares the same phylogenic origin with that of mammals (7).

In the present study, the relative thicknesses of each of the three histological layers at formation, termination and intermediate levels of the venae cavae were measured and recorded so as to study the growth of each of these layers with increasing age. Such quantitative mensuration of individual histological layers with respect to age and level of section has not been reported in previous studies. Qualitative assessment of the histological characteristics of each tunic with respect to age in each of these levels was also carried out.

DOI: http://dx.doi.org/10.4314/ejhs.v30i3.10 


\section{MATERIALS AND METHODS}

Tenfoetal cadavers - 3 each, of age within first and second trimesters, and 4 of age within third trimester - and 10 adult cadavers stored in standard fixative, that is, $10 \%$ formalin were procured for this study after due clearance from the Institutional Ethics Committee (Reg No. ECR/146/Inst/KA/2013/RR-16). The said cadavers showed no signs of external or internal deformity or injury visible to the naked eye. Nor did any of them have any known history of major congenital or acquired disease. The Superior and Inferior Venae Cavae of each cadaver were exposed after dissecting the thoracic and abdominal cavities, respectively. Portions from the regions of formation, termination and an intermediate one between the former two, were excised and fixed in $10 \%$ formalin. Thereafter, each of the tissues were taken through increasing grades of ethyl alcohol for the purpose of dehydration. Subsequently, the tissues were cleared in xylol, and then embedded in blocks of paraffin wax. Suitable sections of 5-micron thickness were acquired from the blocks and adhered to glass slides using Myer's Albumin. The slides were subjected to standard HaematoxylinEosin (H\&E) staining later they were mounted with DPX mountant.

The slides were then observed under a light microscope and the qualitative and quantitative (dimensional) features of the vessels were observed and recorded. The former mainly consisted of assessment of the presence of various histological features in the different tunics of the vessels, especially the cell types present, level of maturity of each tunic and presence of notable musculature such as longitudinal and cardiac types, whereas the latter consisted of measurement of each of the three histological layers of the vessel wall using the software Image Pro. The data thus obtained was then assessed statistically calculating the mean and standard deviation, and then subjecting the data to One Way ANOVA and Tukey's Test for comparative purposes. The results thereof were recorded in tabular form.

\section{RESULTS}

The present study consisted of two main categories of assessment, namely, quantitative and qualitative. The results obtained therefrom are presented as follows:

Quantitative results: The quantitative findings are presented in Table 1 and Table 2 which not only show the mean thickness of each histological layer in every age group at respective levels of section as also the standard deviation in each case. These values were then subjected to One Way ANOVA for comparison of mean widths of each tunic at each particular level of section for statistical significance. Finally, the significant differences between all possible pairs of mean widths were assessed using Tukey's Test so as to attain specific and direct comparisons between individual groups. Thus, the tables provide a direct index of any existing significant difference in mean thickness of a particular tunic between any given pair of age groups at either of the three levels of section which is manifested by the p-value of Tukey's Test between them being less than 0.05. It is notified here that the values of the adult age group were not considered for Tukey's Test for individual comparison, since it is quite obvious that there would be a significant difference in the mean thickness of tunics between vessels of foetal and adult subjects due to the naturally vast extent of total growth between these age groups. 
Table 1: Measurement of mean thickness and standard deviation of each histological layer of superior vena cava in respective age groups at formation, middle and termination levels of section

\begin{tabular}{|c|c|c|c|c|}
\hline & $\begin{array}{l}1^{\text {st }} \text { Trimester } \\
(\mu \mathrm{m})\end{array}$ & $2^{\text {nd }}$ Trimester $(\mu \mathrm{m})$ & $3^{\text {rd }}$ Trimester $(\mu \mathrm{m})$ & $\begin{array}{l}\text { Adult } \\
(\mu \mathrm{m})\end{array}$ \\
\hline \multicolumn{5}{|l|}{ Formation } \\
\hline Intima & $10.53 \pm 0.71$ & $20.95 \pm 1.69$ & $2255+0.75^{\circledR}$ & $25.05 \pm 0.26$ \\
\hline Media & $110.69 \pm 6.16$ & $142 \pm 3.66^{*}$ & $146.58 \pm 13.39^{\circledR}$ & $200.32 \pm 11.37$ \\
\hline $\begin{array}{l}\text { Adventitia } \\
\text { Middle }\end{array}$ & $1958.88 \pm 110.38$ & $2554.86 \pm 818.63$ & $2999.19 \pm 96.79$ & $3191.30 \pm 260.19$ \\
\hline Intima & $10.05 \pm 0.28$ & $12.43 \pm 0.56$ & $12.81 \pm 0.33$ & $13.06 \pm 0.24$ \\
\hline Media & $61.68 \pm 4.23$ & $77.9 \pm 4.68^{*}$ & $159.5 \pm 2.92^{\#(B)}$ & $253.26 \pm 3.44$ \\
\hline Adventitia & $1198.62 \pm 92.26$ & $1826.09 \pm 22.33^{*}$ & $2080.52 \pm 97.56^{\# B}$ & $2553.29 \pm 78.04$ \\
\hline $\begin{array}{l}\text { Termination } \\
\text { Intima }\end{array}$ & $10.21 \pm 0.87$ & $12.71 \pm 2.47$ & $14.34 \pm 1.71^{\# \circledast}$ & $15.42 \pm .86$ \\
\hline Media & $125.58 \pm 7.75$ & $143.55 \pm 3.32^{*}$ & $147.75 \pm 8.52^{\# 巴}$ & $360.44 \pm 9.28$ \\
\hline Adventitia & $990 \pm 94.65$ & $1329.73 \pm 117.3^{*}$ & $1638.95 \pm 174.90^{\# ®}$ & $3835.61 \pm .232$ \\
\hline
\end{tabular}

${ }^{*}$ pvalue $<0.05$ between $1^{\text {st }}$ and $2^{\text {nd }}$ trimester, ${ }^{\#}$ pvalue $<0.05$ between $1^{\text {st }}$ and $3^{\text {rd }}$ trimester, ${ }^{\circledR}$ pvalue $<0.05$ between $2^{\text {nd }}$ and $3^{\text {rd }}$ trimester

Table 2: Measurement of mean thickness and standard deviation of each histological layer of inferior vena cava in respective age groups at formation, middle and termination levels of section

\begin{tabular}{|c|c|c|c|c|}
\hline & $\begin{array}{l}1^{\text {st }} \text { Trimester } \\
(\mu \mathrm{m})\end{array}$ & $\begin{array}{l}2^{\text {nd }} \text { Trimester } \\
(\mu \mathrm{m})\end{array}$ & $\begin{array}{l}3^{\text {rd }} \text { Trimester } \\
(\mu \mathrm{m})\end{array}$ & $\begin{array}{l}\text { Adult } \\
(\mu \mathrm{m})\end{array}$ \\
\hline \multicolumn{5}{|l|}{ Formation } \\
\hline Intima & $6.35 \pm 1.55$ & $10.36 \pm 0.50^{*}$ & $10.73 \pm 0.48^{\circledR}$ & $15.5 \pm 1.09$ \\
\hline Media & $85.44 \pm 5.42$ & $9482 \pm 6.09^{*}$ & $181.28 \pm 8.44^{\#}$ & $282.26 \pm 20.08$ \\
\hline Adventitia & $920.6 \pm 33.84$ & $1265 \pm 61.06^{*}$ & $1273.18 \pm 65.10^{\# \circledast}$ & $2165.21 \pm 147.5$ \\
\hline \multicolumn{5}{|l|}{ Middle } \\
\hline Intima & $11.41 \pm 1.13$ & $11.66 \pm 0.5$ & $12.5 \pm 1.73$ & $13.42 \pm 1.99$ \\
\hline Media & $120.2 \pm 3.29$ & $173.8 \pm 5.06^{*}$ & $231.19 \pm 26.3^{\# \circledast}$ & $256.83 \pm 0.89$ \\
\hline Adventitia & $823.24 \pm 6.21$ & $976.45 \pm 19.52$ & $1016.56 \pm 126.26$ & $2086.09 \pm 150$ \\
\hline \multicolumn{5}{|l|}{ Termination } \\
\hline Intima & $8.99 \pm 0.98$ & $9.49 \pm 8.75$ & $10 \pm 1.86$ & $11.46 \pm 1.38$ \\
\hline Media & $152.56 \pm 15$ & $180.32 \pm 4.44^{*}$ & $486.14 \pm 31^{\#}$ & $564.48 \pm 57.8$ \\
\hline Adventitia & $986.57 \pm 53.09$ & $2726.59 \pm 119.49$ & $2868.72 \pm 50.82^{\# \circledast}$ & $3796.56 \pm 245.3$ \\
\hline
\end{tabular}

${ }^{*}$ pvalue $<0.05$ between $1^{\text {st }}$ and $2^{\text {nd }}$ trimester, ${ }^{\#}$ pvalue $<0.05$ between $1^{\text {st }}$ and $3^{\text {rd }}$ trimester, ${ }^{\circledR}$ pvalue $<0.05$ between $2^{\text {nd }}$ and $3^{\text {rd }}$ trimester

Qualitative results: The qualitative results for superior vena cava and inferior vena cava are summarized in Tables 3 and 4.

DOI: http://x.doi.org/10.4314/ejhs.v30i3.10 
Table 3: Differentiation of tunics and histogenesis -superior vena cava (at formation, middle and termination level). TI- Tunica Intima, TM- Tunica Media, TA- Tunica Adventitia. - Undifferentiated, + Differentiated, ++ Defined, +++ Well-defined

\begin{tabular}{|c|c|c|c|c|c|c|}
\hline \multirow[t]{2}{*}{ Age } & \multicolumn{3}{|c|}{ Tunics } & \multicolumn{3}{|c|}{ Cell types, fibre \& musculature } \\
\hline & Formation & Middle & Termination & Formation & Middle & Termination \\
\hline $1^{\text {st }}$ Trimester & $\begin{array}{c}\mathrm{TI}+, \mathrm{TM} \\
-, \mathrm{TA}-\end{array}$ & $\begin{array}{c}\mathrm{TI}+, \mathrm{TM} \\
-, \mathrm{TA}-\end{array}$ & $\begin{array}{c}\mathrm{TI}+, \mathrm{TM}- \\
\mathrm{TA}-\end{array}$ & $\begin{array}{c}\text { Collagen } \\
\text { appreciable, } \\
\text { mesenchymal } \\
\text { cells \& } \\
\text { fibroblasts } \\
\text { present }\end{array}$ & $\begin{array}{c}\text { Collagen } \\
\text { present, } \\
\text { mesenchymal } \\
\text { cells exceed } \\
\text { mature } \\
\text { fibroblasts, } \\
\text { musculature } \\
\text { prominent in } \\
\text { media }\end{array}$ & $\begin{array}{c}\text { Mesenchymal } \\
\text { cells \& } \\
\text { collagen } \\
\text { appreciable, } \\
\text { pseudo- } \\
\text { discontinuous } \\
\text { musculature } \\
\text { in media }\end{array}$ \\
\hline $2^{\text {nd }}$ Trimester & $\begin{array}{l}\mathrm{TI}+, \mathrm{TM}- \\
\quad, \mathrm{TA}- \\
\text { capillary- } \\
\text { sized vasa } \\
\text { vasorum }\end{array}$ & $\begin{array}{l}\mathrm{TI}+, \mathrm{TM} \\
-, \text { TA - } \\
\text { capillary- } \\
\text { sized } \\
\text { vasa } \\
\text { vasorum }\end{array}$ & $\begin{array}{l}\mathrm{TI}++, \mathrm{TM} \\
++, \mathrm{TA}++ \\
\text { vasa } \\
\text { vasorum } \\
\text { capillary- } \\
\quad \text { sized }\end{array}$ & $\begin{array}{l}\text { Collagen } \\
\text { increased in } \\
\text { amount, } \\
\text { mesenchymal } \\
\text { cells \& } \\
\text { fibroblasts } \\
\text { present }\end{array}$ & $\begin{array}{c}\text { Mesenchymal } \\
\text { cells exceed } \\
\text { mature } \\
\text { fibroblasts, } \\
\text { musculature } \\
\text { prominent in } \\
\text { media }\end{array}$ & $\begin{array}{l}\text { Pseudo- } \\
\text { discontinuous } \\
\text { musculature } \\
\text { in media, } \\
\text { cardiac } \\
\text { musculature } \\
\text { seen }\end{array}$ \\
\hline $3^{\text {rd }}$ Trimester & $\begin{array}{l}\mathrm{TI}++, \mathrm{TM} \\
++, \mathrm{TA}++\end{array}$ & $\begin{array}{l}\mathrm{TI}++, \\
\mathrm{TM}++, \\
\mathrm{TA}++\end{array}$ & $\begin{array}{c}\mathrm{TI}+++, \mathrm{TM} \\
+++, \mathrm{TA} \\
+++\end{array}$ & $\begin{array}{l}\text { Collagen } \\
\text { arranged } \\
\text { orderly, } \\
\text { mesenchymal } \\
\text { cells \& } \\
\text { muscle fibres } \\
\text { present in } \\
\text { media }\end{array}$ & $\begin{array}{l}\text { Collagen } \\
\text { appreciable, } \\
\text { mature } \\
\text { fibroblasts } \\
\text { exceed } \\
\text { mesenchymal } \\
\text { cells, cardiac } \\
\text { musculature } \\
\text { appreciated, } \\
\text { smooth muscle } \\
\text { present in } \\
\text { adventitia }\end{array}$ & $\begin{array}{c}\text { Media } \\
\text { showed } \\
\text { mature \& } \\
\text { continuous } \\
\text { musculature }\end{array}$ \\
\hline Adult & $\begin{array}{c}\mathrm{TI}++, \mathrm{TM} \\
++, \mathrm{TA} \\
+++\end{array}$ & $\begin{array}{c}\mathrm{TI}+++, \\
\mathrm{TM}+++, \\
\mathrm{TA}+++\end{array}$ & $\begin{array}{c}\mathrm{TI}+++, \text { TM } \\
+++, \text { TA } \\
+++\end{array}$ & $\begin{array}{c}\text { Well-defined } \\
\text { musculature } \\
\text { in media }\end{array}$ & $\begin{array}{c}\text { Prominent } \\
\text { musculature in } \\
\text { media as well as } \\
\text { adventitia }\end{array}$ & $\begin{array}{l}\text { Myocytes } \\
\text { abundant, } \\
\text { cardiac } \\
\text { musculature } \\
\text { seen, } \\
\text { adventitia } \\
\text { showed } \\
\text { musculature }\end{array}$ \\
\hline
\end{tabular}

DOI: http://dx.doi.org/10.4314/ejhs.v30i3.10 
Table 4. Differentiation of tunics and histogenesis -inferior vena cava (at formation, middle and termination level). TITunica Intima, TM- Tunica Media, TA- Tunica Adventitia. - Undifferentiated, + Differentiated, ++ Defined, +++ Well-defined

\begin{tabular}{|c|c|c|c|c|c|c|}
\hline \multirow[t]{2}{*}{ Age } & \multicolumn{3}{|c|}{ Tunics } & \multicolumn{3}{|c|}{ Cell types, fibre \& musculature } \\
\hline & Formation & Middle & Termination & Formation & Middle & Termination \\
\hline $\begin{array}{l}\mathbf{1}^{\text {st }} \\
\text { Trimester }\end{array}$ & $\begin{array}{c}\mathrm{TI}+++, \text { TM } \\
+++, \text { TA } \\
+++\end{array}$ & $\begin{array}{l}\mathrm{TI}+, \mathrm{TM} \\
+, \mathrm{TA}+\end{array}$ & $\begin{array}{c}\mathrm{TI}+, \mathrm{TM}+, \\
\mathrm{TA}+\end{array}$ & $\begin{array}{c}\text { Mesenchymal } \\
\text { cells \& collagen } \\
\text { prominent }\end{array}$ & $\begin{array}{c}\text { Mesenchymal } \\
\text { cells \& } \\
\text { fibroblasts } \\
\text { present }\end{array}$ & $\begin{array}{c}\text { Primitive } \\
\text { musculature in } \\
\text { media }\end{array}$ \\
\hline $\begin{array}{l}2^{\text {nd }} \\
\text { Trimester }\end{array}$ & $\begin{array}{c}\text { TI +++, TM } \\
+++, \text { TA } \\
+++ \\
\text { capillary- } \\
\text { sized vasa } \\
\text { vasorum }\end{array}$ & $\begin{array}{c}\text { TI +, TM } \\
++, \text { TA + } \\
\text { vasa } \\
\text { vasorum } \\
\text { capillary- } \\
\text { sized }\end{array}$ & $\begin{array}{c}\mathrm{TI}+, \mathrm{TM}+ \\
\mathrm{TA}+ \\
\text { vasa vasorum } \\
\text { constituted by } \\
\text { arterioles \& } \\
\text { venules }\end{array}$ & $\begin{array}{l}\text { Collagen } \\
\text { increased, } \\
\text { musculature in } \\
\text { media ill- } \\
\text { defined, } \\
\text { abundant } \\
\text { mesenchymal } \\
\text { cells \& } \\
\text { fibroblasts }\end{array}$ & $\begin{array}{l}\text { Mesenchymal } \\
\text { cells \& } \\
\text { fibroblasts } \\
\text { present, } \\
\text { collagenous } \\
\text { stroma } \\
\text { prominent }\end{array}$ & $\begin{array}{l}\text { Fibroblast } \\
\text { exceeded } \\
\text { mesenchymal } \\
\text { cells, collagen } \\
\text { bundles } \\
\text { prominent, } \\
\text { primitive } \\
\text { musculature in } \\
\text { media }\end{array}$ \\
\hline $\begin{array}{l}3^{\text {rd }} \\
\text { Trimester }\end{array}$ & $\begin{array}{c}\mathrm{TI}+++, \mathrm{TM} \\
+++, \mathrm{TA} \\
+++\end{array}$ & $\begin{array}{c}\mathrm{TI}++, \mathrm{TM} \\
+++, \mathrm{TA} \\
++\end{array}$ & $\begin{array}{c}\mathrm{TI}++, \mathrm{TM}++ \\
\mathrm{TA}++\end{array}$ & $\begin{array}{c}\text { Abundant } \\
\text { mesenchymal } \\
\text { cells \& } \\
\text { fibroblasts }\end{array}$ & $\begin{array}{l}\text { Fibroblasts } \\
\text { exceed } \\
\text { mesenchymal } \\
\text { cells, } \\
\text { musculature } \\
\text { prominent in } \\
\text { media }\end{array}$ & $\begin{array}{c}\text { Primitive } \\
\text { musculature in } \\
\text { media, } \\
\text { mesenchymal } \\
\text { cells \& } \\
\text { hyalinized } \\
\text { collagen } \\
\text { bundles also } \\
\text { present }\end{array}$ \\
\hline Adult & $\begin{array}{c}\mathrm{TI}+++, \mathrm{TM} \\
+++, \mathrm{TA} \\
+++\end{array}$ & $\begin{array}{l}\mathrm{TI}+++ \\
\mathrm{TM}+++ \\
\mathrm{TA}+++\end{array}$ & $\begin{array}{c}\mathrm{TI}+++, \mathrm{TM} \\
+++, \mathrm{TA}+++\end{array}$ & $\begin{array}{l}\text { Musculature } \\
\text { prominent in } \\
\text { media, collagen } \\
\text { bundles } \\
\text { hyalinized, } \\
\text { adventitia } \\
\text { showed smooth } \\
\text { muscle }\end{array}$ & $\begin{array}{l}\text { Fibroblasts } \\
\text { prominent, } \\
\text { collagen } \\
\text { bundles } \\
\text { hyalinized, } \\
\text { musculature } \\
\text { compact, } \\
\text { adventitia } \\
\text { showed } \\
\text { musculature }\end{array}$ & $\begin{array}{c}\text { Media showed } \\
\text { mature } \\
\text { musculature \& } \\
\text { fibroblasts, } \\
\text { adventitia } \\
\text { showed } \\
\text { musculature }\end{array}$ \\
\hline
\end{tabular}

Routine staining (H \& E staining) (Figures 1 and 2): The following qualitative features were observed in either vena cava at each level of section in each of the respective age groups:

Endothelium: All groups of vessels of ages ranging from the first trimester up to adult showed a well-defined Tunica Intima consisting mainly of a single layer of flattened cells over a basement membrane forming the endothelium along with some subendothelial connective tissue. There was not much noteworthy change in the structure of this layer with advance in age.
Differentiation of the two outer tunics: In the superior venae cavae, the Tunica Media and the Tunica Adventitia were not well distinguishable in the early stages of development, but appeared as a merged, ill-defined layer. Such merging was seen up to the $2^{\text {nd }}$ trimester in the formation region, $3^{\text {rd }}$ trimester in the middle region and $1^{\text {st }}$ trimester in thetermination region. The differentiation, therefore, may be said to have taken place fastest in the termination and slowest in the middle. In the inferior venae cavae, however, it showed differentiation among these layers right from the $1^{\text {st }}$ trimester itself.

DOI: http://dx.doi.org/10.4314/ejhs.v30i3.10 


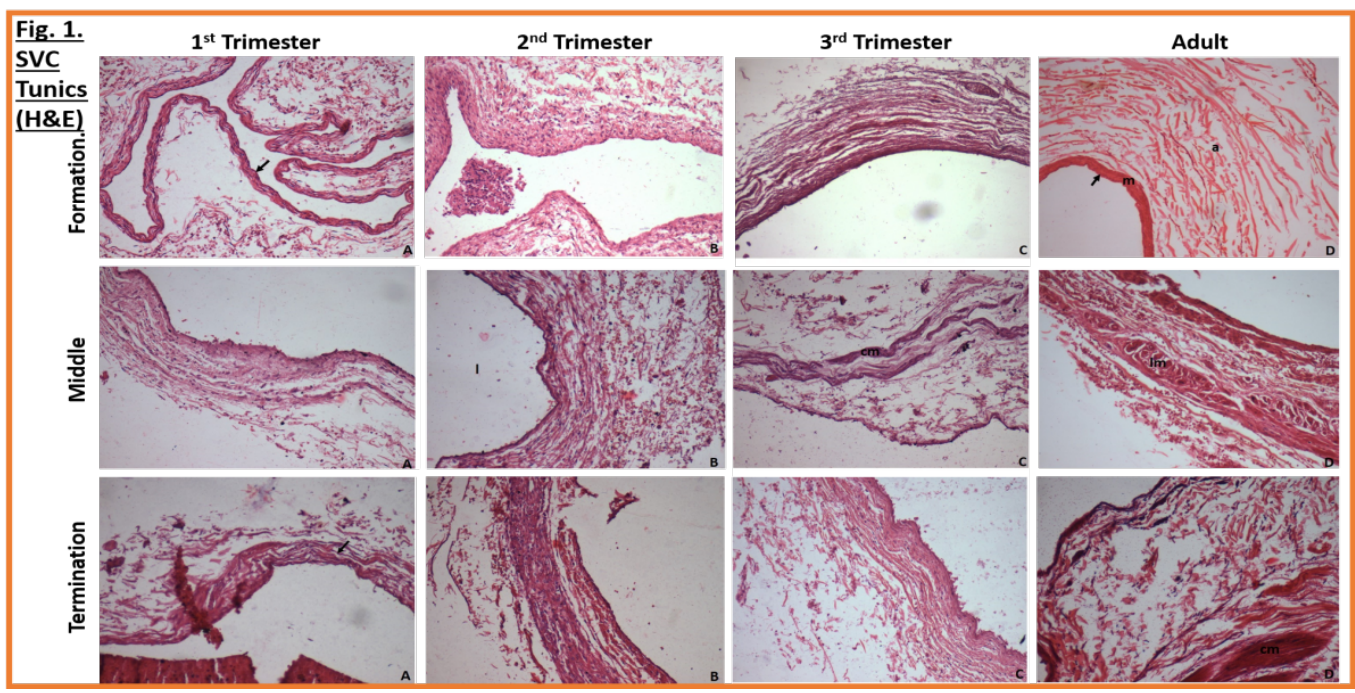

Figure 1: Histological section of superior vena cava $\boldsymbol{H} \& \boldsymbol{E}$ Stain at $10 X$. At the level of formation- A: $1^{\text {st }}$ Trimester; arrow: Endothelium. B: $2^{\text {nd }}$ Trimester. C: $3^{\text {rd }}$ Trimester. D: Adult; arrow: Tunica Intima, m: Tunica Media, a: Tunica Adventitia. At middle- A: $1^{\text {st }}$ Trimester. B: $2^{\text {nd }}$ Trimester; l: Lumen. C: $3^{\text {rd }}$ Trimester; cm: Cardiac Muscle. D: Adult; Im: Longitudinal Muscle. At the level of termination- A: $1^{\text {st }}$ Trimester; arrow; Collagen Bundle. B: $2^{\text {nd }}$ Trimester. C: $3^{\text {rd }}$ Trimester. D: Adult; cm: Cardiac Muscle

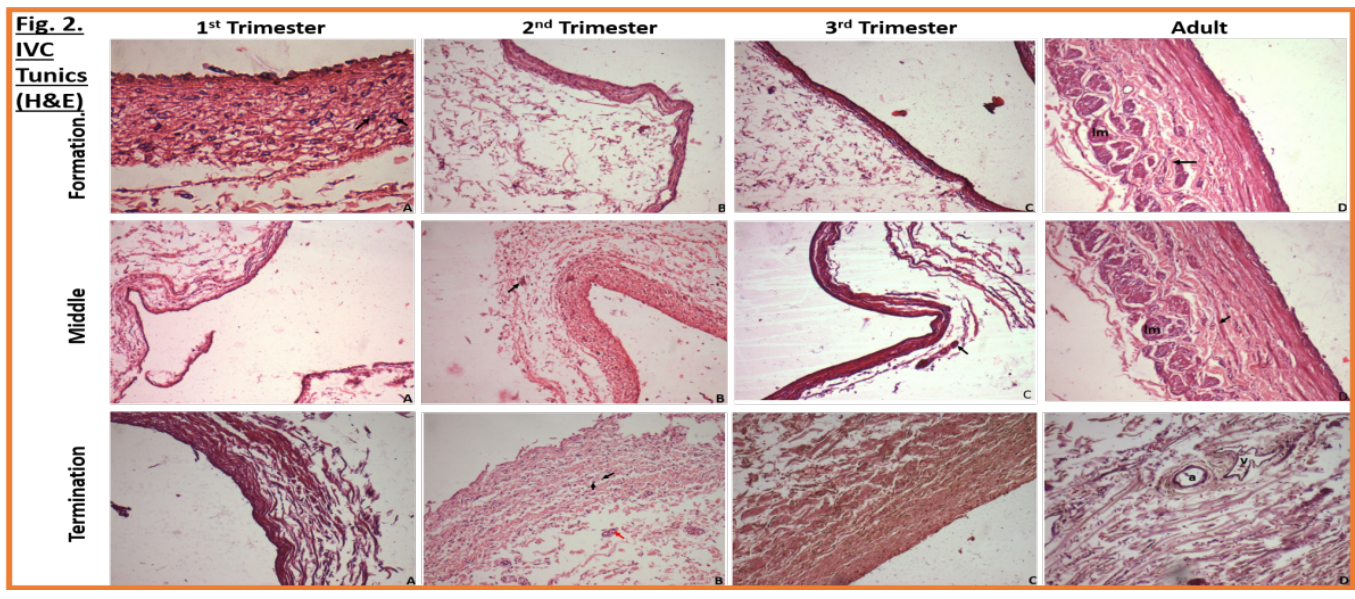

Figure 2: Histological section of inferior vena cava $H \& E$ stain at $10 \mathrm{X}$. At the level of formation- A: 1st Trimester; arrow: Primitive Mesenchymal Cell. B: 2nd Trimester. C: 3rd Trimester. D: Adult; lm: Longitudinal Muscle, arrow: Hyalinized Collagen Bundle. At middle- A: 1st Trimester. B: 2nd Trimester; arrow: Vasa Vasorum Capillary. C: $3 r d$ Trimester; arrow: Vasa Vasorum Capillary. D: Adult; lm: Longitudinal Muscle; arrow: Hyalinized Collagen Bundle. At the level of termination- A: 1st Trimester. B: 2nd Trimester; black arrow: Fibroblast Nucleus, red arrow: Vasa Vasorum Capillary. C: 3rd Trimester. D: Adult; a: Vasa Vasorum Arteriole, v: Vasa Vasorum Venule

Tunica media: The undifferentiated layer comprising the future two outer tunics, as well as well-differentiated Tunica Media showed the following comparable features:

- The bulk of this layer was formed by the circular smooth muscle.
- The main connective tissue component was formed by bundles of collagen fibres that increased in content with advancing age in all the vessels assessed and formed a kind of matrix in which the other components of the Media are interspersed. 
- The Media showed two conspicuous cell types other than the smooth muscle fibres.

○ The primitive mesenchymal cells that appeared like plump spindles are thought to be the precursors of mature fibroblasts and smooth muscle fibres. They were present in all foetal vessels, but absent in the adult ones, showing a transition into mature cell types.

- The mature fibroblast cells were present from the $1^{\text {st }}$ trimester itself, although their concentration was much diminished in the earlier stages as compared to that of undifferentiated mesenchymal cells. With advancing age, the fibroblasts - along with smooth muscle fibres - exceeded their precursors in number. Such an excess of mature cells over primitive cells was first seen in the $3^{\text {rd }}$ trimester (middle portion) in case of superior vena cava and in the $2^{\text {nd }}$ trimester (termination) in case of inferior vena cava, showing the latter matured at a faster rate than the former.

- The Media and its merged precursor both showed a certain amount of lose connective tissue, the amount declined with advancing age.

- The Media tended to vary in thickness and order in foetal vessels but became more uniform and compact in the adult ones. Such compaction was first observed first in the $3^{\text {rd }}$ trimester (middle portion) of the inferior vena cava, once again suggesting that the vessel developed faster than its cranial counterpart.

Tunica Adventitia: The Tunica Adventitia was first distinguishable from the Tunica Media in the $2^{\text {nd }}$ trimester (termination) in case of superior vena cava and in the $1^{\text {st }}$ trimester in case of inferior vena cava, once again vouching for the greater development rate of the latter.

It shows the following features:

- It was composed mainly of loose connective tissue matrix.

- It bore a network of minute vessels constituting the Vasa Vasorum that perfuses the outer layers of the vessels.
Such vessels were first observed in the $3^{\text {rd }}$ trimester (termination) in case of superior vena cava and in the $2^{\text {nd }}$ trimester (formation) in case of inferior vena cava. The vessels were mostly capillary-sized, except in the terminal portion of the adult inferior vena cava, where they clearly resembled well-formed arterioles and venules.

- The Adventitia first showed longitudinal muscle fibres only in the adult vessels. The terminal portion of the inferior vena cava however, consistently lacked longitudinal muscle.

- The Adventitia of the inferior vena cava shows hyalinized collagen bundles in the $3^{\text {rd }}$ trimester (termination) and adult vessels.

Longitudinal Musculature: Longitudinal musculature was partly seen in the Tunica Adventitia of the adult superior vena cava at the middle level as also at that of its termination.

It was also encountered in the Adventitia of the adult inferior vena cava at the level of it formation and middle. It is lacking in foetal vessels as also at the level of termination of the adult inferior vena cava.

Cardiac Musculature: Cardiac musculature of the superior vena cava was first seen in the middle section of the $3^{\text {rd }}$ trimester, where it spanned parts of both tunica adventitia and media. It was also seen at the level of termination in the $2^{\text {nd }}$ trimester group, as also in the adult group. Thus, it tends to appear with increasing age and proximity to the heart. Cardiac musculature was not seen in significant amount in the inferior vena cava.

\section{DISCUSSION}

The main findings of the present study revolve around certain histological characteristics - both qualitative and quantitative - observed in each vessel from a respective age group and level of section and compared subsequently to those of the other kinds of vessel to establish trends or patterns of tissue distribution and growth spanning over the various groups.

It is mentioned at this point that measurement of thickness of individual tunics in each age group

DOI: http://dx.doi.org/10.4314/ejhs.v30i3.10 
at respective levels of section has not been reported with prominence in previous literature as reviewed for this study and therefore affords no comparison with any earlier studies.

Perhaps the most intriguing aspect of the histological study of the venae cavae or of any of the major blood vessels having proximity to the heart, is the presence of cardiac musculature in their walls.

In the superior vena cava, cardiac musculature has been reported to be seen from the right atrium right up to the root of the subclavian vein and consists of several well-developed circular or spiral layers of smooth muscle, coursing along a length of 2.5-3.0 cm (8). Cardiac myocytes extended into the superior vena cava in $78 \%$ of subjects. ${ }^{9}$ The superior vena cava has been reported to contain cardiac muscle fiber outside the smooth muscle layer, distributed continually from the atrium to the root of the azygos vein, occupying one to two thirds of the wall thickness (4). In the present study, cardiac musculature of the superior vena cava was first reported in the middle section of the $3^{\text {rd }}$ trimester, where it spanned parts of both tunica adventitia and media. It was also seen at the level of termination in the $2^{\text {nd }}$ trimester group, as also in the adult group. Thus, it tends to appear with increasing age and proximity to the heart.

The opinion regarding presence of cardiac musculature in the inferior vena cava has varied between authors. While some have reported that the inferior vena cava also contained cardiac muscle fibers extending from the atrium to a level just under the diaphragm, others have reported that they did not extend beyond the pericardium, while still others have reported that no cardiomyocyte extended into the inferior vena cava at all $(4,8,9)$. The findings of the present study agree with the last opinion since no significant amount of cardiac musculature was observed in the inferior vena cava.

The venae cavae can thus be regarded as an extension of the atrium and may in fact, contract together with the atrium, working as a functional valve contributing to the cardiac pumping mechanism (4).

Active contraction of the vessel wall is suggested by the abundance of myofibrils and mitochondria detected within the cytoplasm smooth muscle fibres. This musculature may in fact, play a part in the endocrine function of the atrium as suggested by the presence of an atrial natriuretic polypeptidelike substance in the fibres as revealed by immunohistochemical analysis (7).

The muscular component of the intrapericardial segment of the superior venae cavae may be regarded as a functional sphincter controlling blood flow to the atrium as well as stopping blood flow during the arterial systole (5).

Major literature in this area focuses on the qualitative analysis of the histological characteristics of the venae cavae, concentrating mainly on the presence of cardiac musculature, its extent and distribution, and the clinical implications thereof (2-9). Previous studies have mainly dealt with adult or animal vessels. $(3-7,9)$. In contrast, the present study is noteworthy in the following regards:

- It not only highlights the aspects related to the cardiac musculature of caval veins, but also describes in detail, the other histological characteristics varying among the vessels of different age groups

- It provides an insight into the age-wise correlation between the relative development of various histological features and components in each tunic of these vessels.

- It also provides a detailed quantitative assessment of the alteration of width of each tunic in each age group and presents the statistically significant changes as inferred from the tables provided

- The study incorporates an embryological aspect by the inclusion of fetuses for the purpose of studying the age-related histological changes in the caval veins as an index of their development, which has been a rare occurrence ${ }^{2}$ in the study of the said vessels.

\section{ACKNOWLEDGEMENTS}

The authors want to acknowledge the technicians of Anatomy Department who helped in processing the tissue for histological preparations. There is no

DOI: http://dx.doi.org/10.4314/ejhs.v30i3.10 
conflict of interest between the authors. This research did not receive any specific grant from funding agencies in the public, commercial, or notfor-profit sectors.

\section{REFERENCES}

1. Standring S, Borley NR, \& Gray H. Gray's anatomy: the anatomical basis of clinical practice. 40th ed., anniversary ed. [Edinburgh]:

Churchill Livingstone/Elsevier; 2008.

2. Ross MH, \& Pawlina W. Histology: A text and atlas: with correlated cell and molecular biology. Baltimore, MD: Lippincott Wiliams \& Wilkins; 2006.

3. Endo H, Mifune H, Kurohmaru M, Hayashi Y. Cardiac Musculature Of The Cranial Vena Cava I The Rat. Acta Anat (Basel).1994; 151(2):107-11.

4. Hashizume H, Ushiki T, Abe KA. histological study of the cardiac muscle of the human superior and inferior venae cavae. Arch Histol Cytol.1995; 58(4):45764.

5. Piffer CR, Piffer MI, Santi FP, Dayoub MC. Structural characteristics of the superior venae cavae wall at the intrapericardium segment in adults and aging individuals. Okajimas Folia Anat Jpn. 1996; 73(2-3):89-100.

6. Endo H, Maeda S, Kimura J, Yamada J, Rerkamnuaychoke W, Chungsamarnyart N, Tanigawa M, Kurohmaru M, Hayashi Y, Nishida T. Cardiac musculature of the cranial vena cava in the common tree shrew (Tupaia glis). J Anat.1995; 187 (Pt. 2):347-52.

7. Endo $\mathrm{H}$, Kurohmaru $\mathrm{M}$, Nishida $\mathrm{T}$, Hayashi Y Cardiac musculature of the cranial and caudal venae cavae and the pulmonary vein in the fowl. Vet Med Sci.1992; 54(3):479-84.

8. Rusakov DY, Yamshchiko NV, Tulayeva ON, Suvorova LA, Metlenko OI. Histogenesis and Peculiarities of Structural Organisation of the Cardiac Muscle Tissue in the Walls of Human Caval and Pulmonary Veins. Morfologiia, 2015; 148(6):38-42.

9. DeSimone CV, Noheria A, Lachman N, Edwards WD, Gami AS, Maleszewski JJ, Friedman PA, Munger TM, Hammill SC, Packer DL, Asirvatham SJ. Myocardium of the superior vena cava, coronary sinus, vein of Marshall, and the pulmonary vein ostia: gross anatomic studies in 620 hearts. $J$ Cardiovasc Electrophysiol. 2012; 23(12):1304-9. 